\section{THE ORIGIN OF THE SCENERY OF THE BRITISH ISLANDS ${ }^{1}$}

THE insular position of Britain, which we are accustomed to regard as an essential and aboriginal feature of the country, is merely accidental, and has not always been maintained. The intimate relation of Britain with the Continent is well shown by the Admiralty charts. If the west of Europe were elevated 2ooft.that is, the height of the London Monument-the Straits of Dover, half of the North Sea, ard a large part of the English Channel would be turned into dry land. If the elevation extended to $600 f$. - that is, merely the united heights of St. Paul's and the Monument-the whole of the North Sea, the Baltic, and the English Channel would become land. There would likewise be added to the European area a belt of territory from IOO to I5O miles broad, stretching to the west of Ireland and Scotland. A vast plain would unite Britain to Denmark, Holland, and Belgium, and would present two platforms, of which the more southerly would stretch from what are now the Straits of Dover northward to the northern edge of the Dogger Bank. The steep declivity separating the two plateaux is doubtless a prolongation of the Jurassic and Cretaceous escarpments of Yorkshire. It is trenched at either end by marked depressions, of which the western is a magnificent valley through which the united waters of the Rhine and Thames would flow between the Dogger Bank and the Yorkshire cliffs. The eastern gap would allow the combined Elbe and Weser to escape into the northern plain. Possibly all those rivers would unite on that plain, but, in any case, they would fall into a noble fjord which would then be revealed following the southern coast line of Norway. Altogether an area more than thrice that of Britain would be added to Europe. By a total rise of $\mathbf{I}, 800$ feet, Britain would be united to the Faroe Islands and Iceland; while the Arctic and Atlantic Oceans would be separated. From its position on the oceanic border of a continent, Britain has been exposed to a great variety of geological change. In such a position marine erosion and deposit are most active, and a slight upheaval or depression, which would have no sen-ible effect in the interior of a continent, makes all the difference between land and water. Moreover, there appears to be a tendency to special disturbance along the edge of an ocean. America affords the most marked proofs of this tendency, but in the structure of Scandinavia and its prolongation into Scotland and Ireland there appear to be traces of similar ancient ridging up of the oceanic border of Europe.

There is a remarkable convergence of geological formations in Britain, each carrying with it its characteristic scenery. The rugged crystalline rocks of Norway reappear in the Scottish Highlands; the fertile Chalk, with its smooth downs and gentle escarpment, stretches across to us from the north of France the great plains of North Germany, strewn with the debris of the northern hills, extends into our eastern lowlands; even the volcanic plateaux of Iceland and Faroe are prolonged into the Inner Hebrides and the north of Ireland.

The present surface of Britain is the result of a long, complicated process in which underground movements, though some times potent, have only operated occasionally, while superficial erosion has been continuous, so long as any land has remained above the sea. The order of appearance of the existing features is not necessarily that of the chronological sequence of the rocks. The oldest formations have all been buried under later accumulations, and their re-emergence at the surface has only been brought about after enormous denudation. In its general growth, Britain like the rest of Europe has, on the whole, increased from the north by successive additions along its southern border. The oldest upheavals ridged up the Palæozoic rocks into folds running northnorth-east and south-south-west, as may yet be seen in Scotland, in the Lake Country, and in Wales. By a later series of folds the younger Palæozoic rocks were thrown into north and south and east and west ridges, the latter of which still powerfully affect the topography in southern. Ireland, and thence through South Wales and Belgium. An east and west direction was followed by the more important subsequent European disturbances, such as those that upheaved the Pyrenees, Jura, and Alps. Some of the latest movements that have powerfully affected the development of our scenery were those that gave the Secondary rocks their general tilt to south-east. It is very doubtful if any part of the existing topography can be satisfactorily traced back beyond middle or older Tertiary time. The amount of erosion

I Abstract of the first of five lectures by Archibald Geikie, F. R. S., DirectorGeneral of the Geological Survey, given at the Royal Institution, January 29. of some of the hardest rocks of the country since that date has been prodigious, as may be seen in the fragmentary condition of the volcanic plateaux of the Inner Hebrides.

The main topographical features of Britain may be arranged as mountains, tablelands, valleys, and plains. All our mountains are the effect of erosion on areas of land successively upheaved above the sea. In the development of their forms, the general outlines have been mainly determined by erosion independent of geological structure; while the details have been chiefly guided by structure, but partially also by the rate and kind of erosion. Ruggedness, for example, has resulted primarily from structure, but has been aggravated by greater activity of erosion. The mountainous west, with a greater rainfall and steeper slopes, is more rugged than the mountainous east. The tablelands of Britain are of two orders- $\mathbf{I}$, those of deposit, which may be either $(a)$ of sedimentary rocks, horizontal or nearly so, as in the millstone grit and Jurassic plateaux of Yorkshire, or $(b)$ of volcanic rocks, as in the wide plateaux of Antrim, Mull, and Skye; 2, those of erosion, where, as the result of long-continued degradation, a series of plicated rocks bas been cut down into a more or less uniformly level surface, as in South Wales, By the elevation of such a surface into a high plateau, erosion begins anew, and the plateau is eventually trenched into a system of ridges and isolated hills, as has happened in the Highlands. The valleys of Britain are the result of erosion either $(a)$ guided by geological structure, as in what are called longitudinal valleys, that is, valleys which run along the strike or outcrop of formations, as the Great Glen and Glen Spey in Scotland and the valleys of the Trent and Avon in England; or $(b)$ independent of geological structure, as in the transverse valleys which embrace the great majority of British examples. Our plains have been produced by the spreading out of detritus by the operation of rain and rivers, as in river terraces and alluvial plains; by the sea, as in raised beaches; or by land-ice and floating-ice, as in the glacial drifts of the Lowlands. The existing watershed of Britain is profoundly significant, affording a kind of epitome of the geological revolutions through which the surface of the country has passed. It lies nearer the west than the east coast. The western slope being thus the steeper, as well as the more rainy, erosion must be greater on that side, and consequently the watershed must be slowly moving eastward. Probably the oldest part of the watershed is to be found in the Highlands, where its trend from north-north-east to south-south-west was determined by the older Palæozoic upheaval. Its continuity has been interrupted by the dislocation of the Great Glen. After quitting the Highlands it wanders across the Scottish Lowlands and Southern Uplands, with no regard to the dominant geological structure of these districts, as if, when its course was originally determined, they had been buried under so vast a mass of superincumbent rock that their structure did not affect the surface. Running down the Pennine Chain the watershed traverses a region of enormous erosion, yet from its general coincidence with the line of the axis of elevation, we may perhaps infer that the anticline of the Pennine Chain has never been lost under an overlying sheet of later undisturbed rocks. The remarkable change in the character of the watershed south of the Pennine Chain carries us back to the time when the great plain of the Secondary rocks of England was upraised with a gentle inclination to east-and southeast. The softer strata between the harder escarpment-forming members of the Jurassic series and the Palæozoic rocks of the Pennine Chain were worn away, and two rivers carrying off the drainage of the southern end of that chain flowed in opposite directions, the Avon turning south-west and the Trent northwards. By degrees these streams moved away across the broadening plain of softer strata as the escarpments emerged and retreated. At the same time streams collected the drainage from the uprising slope of Secondary rocks and flowed south. eastward. Successive lines of escarpment have since been developed, and many minor watersheds have arisen, while the early watershed has undergone much modification, these various changes pointing to the continuous operation of running water.

\section{SOCIETIES AND ACADEMIES LoNDaN}

Royal Society, December 13, 1883.- " Experimental Researches on the Electric Discharge with the Chloride of Silver Battery." By Warren De La Rue, M.A., D.C.L., Ph.D., F.R.S., and Hugo W. Müller, Ph.D., F.R.S. 